\title{
Angka Kejadian Gejala Infeksi Saluran Kemih pada Ibu Hamil di Desa Mekargalih Kecamatan Jatinangor Kabupaten Sumedang Tahun 2014
}

\author{
Alvie Rizky Gusrianty ${ }^{1}$, Sri Astuti $^{2}$, Hartinah $^{3}$, Ari Indra Susanti \\ ${ }^{1}$ Program Studi Kebidanan Fakultas Kedokteran Universitas Padjadjaran \\ ${ }^{2}$ Departemen Ilmu Kesehatan Masyarakat Fakultas Kedokteran Universitas Padjadjaran \\ ${ }^{3}$ Departemen Biostatistik dan Epidemiologi Fakultas Kedokteran Universitas Padjadjaran
}

\begin{abstract}
Abstrak
Infeksi saluran kemih (ISK) sering ditemukan pada kehamilan disebabkan adanya perubahan fisiologis pada saluran kemih sepanjang kehamilan sehingga meningkatkan risiko ISK. Penelitian ini bertujuan untuk mengetahui angka kejadian gejala ISK pada ibu hamil di Desa Mekargalih. Metode penelitian yang digunakan adalah deskriptif dengan pendekatan cross sectional. Data diambil menggunakan kuesioner dengan mendatangi setiap rumah ibu hamil. Populasi ibu hamil sebanyak 73 orang. Jenis pengambilan sampel menggunakan total sampling dan termasuk ke dalam kriteria inklusi, kemudian didapat sebanyak 63 orang. Analisa data menggunakan rumus univariat secara manual dan komputerisasi (MS. Excel). Penelitian dilaksanakan pada tanggal 10 -14 Maret 2014. Hasil penelitian menunjukkan bahwa angka kejadian gejala ISK pada ibu hamil adalah $30,2 \%$, gejala yang paling banyak dialami adalah tidak bisa menahan buang air kecil (37,9\%), berdasarkan usia kehamilan paling banyak terjadi pada usia kehamilan 28-40 minggu (17,5\%), berdasarkan pendidikan terbanyak pada pendidikan SMA/SMK (15,9\%). Semakin besar kehamilan maka semakin rentan terkena ISK karena memungkinkan terjadinya obstruksioleh besarnya uterus yang menyebabkan dilatasi sistem pelviokalises danureter. Puncakinsidensi ISKadalah padausiakehamilan2840 minggu karena hormon progresteron dalam kadar tinggi dan obstruksi oleh uterus yang besar menyebabkan dilatasi system pelviokalises. Kurangnya sumber informasi mengakibatkan kurangnya pengetahuan ibu hamil tentang ISK.
\end{abstract}

Kata kunci :Gejala ISK, ibuhamil, pendidikan, usia kehamilan

\section{The Incidence of Urinary Tract Infection Symptoms in Pregnant Women in Mekargalih Village, Jatinangor Subdistrict, Sumedang 2014}

\begin{abstract}
Urinary tract infection (UTI) is common in pregnancy due to physiological changes in the urinary tract during pregnancy thereby increasing the risk of UTI. This study was conducted to describe the incidence of UTI symptoms among pregnant women in Mekargalih Village. This study was cross sectional study with total sampling technique toward 63 pregnant women that meet the inclusion criterias from 73 pregnant women in Mekargalih Village. The data were analyzed by using univariate formulas manually and computerization(Microsoft Excel). The research was conducted on March 10 to 12, 2014. The results showed that the incidence of UTI symptoms among pregnant women in Mekargalih Village was (30,2\%) and the most common symptom experienced by pregnant women was urinary incontinence (37,9\%). The symptoms most common experienced by 28-40 month gestational age of pregnant women (17,5\%) and pregnant women with High School Education level $(15,1 \%)$. The larger pregnancy makes more susceptible to UTI because it allows the obstruction by the size of the uterus that causes dilation pelvicalyceal system and ureter. The peak incidence of UTI is at 28-40 weeks gestation because of high levels of the progesterone hormone and obstruction by a large uterus can cause dilation of pelvicalyceal system. Lack of information sources leads to a lack of knowledge about ISK for pregnant women.
\end{abstract}

Keywords: Education, gestational age, pregnant women, UTI symptoms

Korespondensi :

Alvie Rizky Gusrianty

Program Studi Kebidanan Fakultas Kedokteran Universitas Padjadjaran

Jl. Raya Bandung Sumedang KM 21 Jatinangor, Sumedang.

Mobile : 085624022600

Email: alvier778@gmail.com 


\section{Pendahuluan}

Ibu hamil merupakan salah satu kelompok masyarakat yang menjadi perhatian dalam pelayanan kesehatan di mana salah satu masalah yang berlaku pada ibu hamil adalah infeksi saluran kemih. Jika infeksi saluran kemih pada ibu hamil ini tidak diatasi dan dicegah, akhirnya akan memberi kesan buruk kepada kesehatan ibu hamil dan mendatangkan komplikasi dalam kehamilan. ${ }^{1}$

Infeksi saluran kemih (ISK) sering ditemukan pada kehamilan, dengan prevalensi rerata sekitar $10 \% .^{2}$ Infeksi saluran kemih dibagi menjadi ISK bagian bawah (bakteriuria asimtomatik, sistitis akut), dan ISK bagian atas (pielonefritis). ISK tidak bergejala (bakteriuria asimtomatik) dan ISK bergejala (sistitis akut dan pielonefritis) masing-masing ditemukan pada $2-13 \%$ dan $1-2 \%$ ibu hamil. ${ }^{3}$ Di Indonesia, prevalensi bakteriuria asimtomatik pada kehamilan adalah $7,3 \%$. Perubahan fisiologis pada saluran kemih sepanjang kehamilan meningkatkan risiko ISK. Pengaruh hormon progesteron dan obstruksi oleh uterus menyebabkan dilatasi sistem pelviokalises dan ureter, serta peningkatan refluks vesikoureter. Tekanan oleh kepala janin juga menghambat drainase darah dan limfe dari dasar vesika, sehingga daerah tersebut mengalami edema dan rentan terhadap trauma. ${ }^{4}$

Infeksi Saluran Kemih telah diketahui berhubungan dengan kesudahan kehamilan yang buruk, seperti persalinan preterm, pertumbuhan janin terhambat, bahkan janin lahir mati (stillbirth). Di Indonesia menurut SDKI menyatakan Angka kematian bayi (AKB) telah menurun dari 35/1000 kelahiran hidup (KH) pada tahun 2004 menjadi34/1000kelahiran hidup pada tahun 2007. ${ }^{5}$ Angka kematian bayi berdasarkan data cakupan Puskesmas Jatinangor pada tahun 2010 adalah $0,7 \%$, tahun 2011 sebesar $0,8 \%$, dan tahun 2012 sebesar 1,0\%.5 Sedangkan angka kejadian BBLR di Desa Mekargalih Kecamatan Jatinangor tahun 2012 yaitu 0,6\%.5 Angka kematian neonatus yang disebabkan BBLR pada tahun 2011 sampai tahun 2012 adalah 7.6 Angka janin yang lahir mati di Kecamatan Jatinangor pada tahun 2012 adalah 3 orang. ${ }^{6}$ Berdasarkan data sepuluh besar rujukan bayi balita di kecamatan Jatinangor, BBLR menempati posisi ke 7 dengan jumlah 7 bayi /balita. ${ }^{6}$

Komplikasi ini bukan hanya akibat ISK bergejala, tetapi bakteriuria asimtomatik juga dapat menyebabkan komplikasi tersebut. ${ }^{2}$ Bakteri patogen dari vesika dapat membentuk koloni pada saluran genitalia bagian bawah, dan menyebabkan korioamnionitis. ${ }^{7}$ Oleh sebab itu, sangat penting bagi seorang dokter dapat melakukan upaya skrining, diagnosis, serta pemberian terapi yang sesuai pada ibu hamil dengan ISK. Begitu juga dengan bidan, sangat penting mengetahui gejala awal ISK untuk mendeteksi dini penyakit ISK pada ibu hamil untuk kemudian diberi konseling dan segera dirujuk jika terdapat gejala-gejala ISK.

Pada sebuah studi yang melibatkan 4.290 sampel kultururin positifdilaporkan bahwa bakteri patogen tersering pada ISK adalah Escherichia coli, diikuti dengan Klebsiella pneumoniae. ${ }^{8}$

Infeksi saluran kemih merupakan suatu keadaan yang tidak dapat diabaikan karena insidennya masih cukup tinggi, yaitu sekitar $5,2 \%{ }^{9}$, sedangkan dari penderita yang berobat ke dokter umum 0,5-1 \% menunjukkan gejala infeksi saluran kemih. ${ }^{11}$ Insiden pada wanita dewasa (5\%) lebih banyak dari pada pria maupun anak - anak, sedangkan pada usia lanjut lebih meningkat dan mencapai 20-50\%. ${ }^{10}$ Frekuensi yang tinggi pada wanita disebabkan oleh karena beberapa faktor, salah satu di antaranya adalah karena saluran uretra wanita lebih pendek sehingga mudah terkontaminasi oleh kumankuman sekitar perianal. ${ }^{11,12}$ Penelitian yang dilakukan terhadap wanita hamil menunjukan bahwa sekitar 7\% memberikan hitung bakteri dalam urine $>100.000$ cfu (colony forming unit)/ $\mathrm{ml}$. Pada wanita yang tidak hamil frekuensinya berkisar antara 2,8\%-22\%. Infeksi nyata terjadi pada kehamilan antara 26 hingga 36 minggu dengan puncak insiden pada kehamilan 3032 minggu. Bakteriuria pada kehamilan dapat berupa: bakteriuria asimtomatik (1\%-1,5\%), sistitis $(3 \%-1,3 \%)$ dan pielonefritis $(1 \%-2 \%)$. Sedangkan penelitian oleh Desmiwarti, ${ }^{13}$ di RSUP Dr M Jamil Padang didapatkan abortus $42 \%$ pada wanita hamil dengan bakteriuria asimtomatik. Insiden pielonefritis akut pada wanita hamil sekitar $33 \%$ dan setelah diberikan pengobatan yang tepat dapat ditekan menjadi $2,8 \%$. Pada $24 \%$ wanita hamil dengan infeksi saluran kemih, bayinya lahir prematur sedangkan setelah diberikan pengobatan yang tepat, kelahiran prematur ini dapat ditekan menjadi $10 \% .^{14}$

Penelitian ini bertujuan mengetahui angka kejadian gejala infeksi saluran kemih pada ibu hamil di Desa Mekargalih Kecamatan Jatinangor Kabupaten Sumedang. Tujuan khususnya mengetahui prevalensi ibu hamil yang mengalami gejala ISK, mengetahui gejala ISK yang paling sering dialami oleh ibu hamil, dan mengetahui angka kejadian gejala ISK berdasarkan karakteristik ibu hamil meliputi umur kehamilan dan pendidikan. 


\section{Metode}

Metode yang digunakan pada penelitian ini adalah metode deskriptif dengan pendekatan cross sectional (potong lintang) yaitu dengan cara pendekatan, observasi atau pengumpulan data sekaligus pada suatu saat. ${ }^{11}$ Pada penelitian ini pengumpulan data dilakukan hanya pada satu waktu selama penelitian. Populasi dalam penelitian ini adalah semua ibu hamil di desa Mekargalih sebanyak 73 orang. Sedangkan, sampel yang didapat yaitu ibu-ibu hamil yang memenuhi kriteria inklusi dan eksklusi sebanyak 63 orang. Pengambilan sampel dengan teknik total sampling. Sampel yang diambil adalah ibu hamil yang memiliki kriteria inklusi yaitu tinggal di Desa Mekar Galih, umur kehamilannya trimester 1,2 , dan 3 , dan berada di tempat saat pengambilan data penduduk dan bersedia untuk diteliti pada tanggal 10-14Maret2014. Sedangkan kriteria eksklusinya adalah tidak bersedia diteliti dan tidak ada ditempat ketika pengambilan data.

Pengolahan data dilakukan dengan cara manual dan komputerisasi (Program Microsoft Excel). Data dianalaisis menggunakan analisis univariat. Dilakukan perhitungan jumlah presentase masing-masing variable yang diteliti dengan rumus $\mathrm{P}=\mathrm{f} / \mathrm{n} \times 100 \%$ ( $\mathrm{P}$ : Presentase, $\mathrm{f}$ : Frekuensi, $\mathrm{n}$ : Sampel). Data disajikan dalam bentuk tabel distribusi frekuensi. ${ }^{18}$

\section{Hasil}

Dari tabel 1 tampak bahwa prevalensi ibu hamil yang mempunyai gejala sebesar 30,2\%. Dari tabel 2 tampak bahwa gejala ISK yang paling banyak dialami ibu hamil adalah tidak bisa menahan BAK yaitu sebesar 37,9 \%. Dari tabel 3 tampak bahwa gejala ISK sebagian besar terjadi pada umur kehamilan 28-40 minggu yaitu 17,5\% dan pada ibu hamil yang pendidikan terakhirnya SMA/SMK yaitu $15,9 \%$.

Tabel 1. Distribusi Ibu Hamil yang mempunyai ISK

\begin{tabular}{|l|c|c|}
\hline $\begin{array}{l}\text { Ada/Tidak } \\
\text { Ada Gejala }\end{array}$ & Frekuensi & $\mathbf{\%}$ \\
\hline Ada gejala & 19 & 30,2 \\
\hline $\begin{array}{l}\text { Tidak ada } \\
\text { gejala }\end{array}$ & 44 & 69,8 \\
\hline Jumlah & $\mathbf{6 3}$ & $\mathbf{1 0 0}$ \\
\hline
\end{tabular}

\section{Pembahasan}

Berdasarkan penelitian yang telah dilakukan, yang mengalami gejala infeksi saluran kemih sebesar $30,2 \%$, gejala infeksi saluran kemih yang paling banyak dialami oleh ibu hamil yaitu tidak bisa menahan BAK sebesar 37,9\%. Menurut teori, infeksi saluran kemih (ISK) sering ditemukan pada kehamilan, dengan prevalensi sekitar $10 \%{ }^{2}$ Infeksi saluran kemih dibagi menjadi ISK bagian bawah (bakteriuria asimtomatik, sistitis akut), dan ISK bagian atas(pielonefritis). ISK tidak bergejala (bakteriuria asimtomatik) dan ISK bergejala (sistitis akut dan pielonefritis) masing-masing ditemukan pada $2-13 \%$ dan $1-2 \%$ ibu hamil. ${ }^{3}$

Teori dan penelitian sebelumnya menyatakan bahwa kejadian ISK pada ibu hamil sebesar $\leq 10 \%$, tetapi pada penelitiaan ini ternyata angka kejadian gejala ISK lebih besar dari angka kejadian ISK menurut teori yaitu 30,2\%. Hal ini bisa disebabkan oleh perbedaan antara penggunaan data objektif pada penelitian di teori dan penggunaan data subjektif tanpa menggunakan data objektif pada penelitian ini (hanya menggunakan data hasil anamnesa gejala ISK yang dialami oleh ibu hamil).

Hasil penelitian ini menunjukkan bahwa yang mengalami gejala ISK dilihat dari umur kehamilan yang paling banyak pada umur kehamilan 28-40 minggu sebesar $17,5 \%$ (11 orang). Secara teori semakin besar kehamilan maka semakin rentan terkena ISK karena memungkinkan terjadinya obstruksi oleh besarnya uterus yang menyebabkan dilatasi system pelviokalises dan ureter. ${ }^{15}$ Pada perempuan yang sedang hamil terjadi perubahan fisiologis seperti pengaruh hormone progresteron dan obstruksi oleh uterus yang menyebabkan dilatasi system pelviokalises dan ureter. ${ }^{19}$ Pada perempuan hamil juga terjadi penurunan tonus ureter dan peristaltiknya, serta peningkatan refluks vesiko ureter karena katup vesiko ureter yang sementara kurang kompeten. ${ }^{15,16}$

Hasil penelitian ini sesuai dengan teori, puncak insidensi infeksi saluran kemih yaitu pada usia kehamilan 30-32 minggu. Hormon progresteron dalam kadar tinggi dan obstruksi oleh uterus yang besar menyebabkan dilatasi system pelviokalises dan ureter sehingga sangat rentan terkena ISK pada usia kehamilan 28-40 minggu. ${ }^{4}$

Dari tabel 3. Hasil penelitian, didapatkan bahwa ibu hamil yang mengalami gejala ISK dilihat dari pendidikan yang paling banyak pada ibu pendidikan terakhir SMA/SMK sebesar $52,6 \%$ (10 orang).Secara teori, peningkatan pengetahuan individu berdampak pada peningkatan perilaku, pola hidup dan kebiasaankebiasaan individu yang berperilaku sehat.

Menurut teori ibu yang berpendidikan tinggi mempunyai resiko ISK yang rendah, tetapi pada 
Alvie Rizky Gusrianty : Angka Kejadian Gejala Infeksi Saluran Kemih pada Ibu Hamil di Desa Mekargalih Kecamatan Jatinangor Kabupaten Sumedang Tahun 2014

Tabel 2. Distribusi frekuensi gejala ISK pada ibu hamil

\begin{tabular}{|l|c|c|}
\hline \multicolumn{1}{|c|}{ Gejala ISK } & Frekuensi & $\mathbf{\%}$ \\
\hline 1. Nyeri buang air kecil (BAK) & 4 & 13,8 \\
\hline 2. Sering buang air kecil dan air kencing yang keluar sedikit (BAK tidak lancar) & 5 & 17,2 \\
\hline 3. Mendadak ingin buang air kecil dan hampir tidak bisa ditahan & 5 & 17,2 \\
\hline 4. Tidak bisa menahan buang air kecil & 11 & 37,9 \\
\hline 5. Nyeri pinggang dan disertai demam & 4 & 13,8 \\
\hline \multicolumn{1}{|c|}{ Jumlah } & $\mathbf{2 9}$ & $\mathbf{1 0 0}$ \\
\hline
\end{tabular}

Tabel 3. Distribusi frekuensi gejala ISK berdasarkan karakteristik ibu hamil

\begin{tabular}{|c|c|c|c|c|}
\hline \multicolumn{5}{|c|}{ Gejala ISK } \\
\hline \multirow[t]{2}{*}{ Karakteristik } & \multicolumn{2}{|c|}{ Ya } & \multicolumn{2}{|c|}{ Tidak } \\
\hline & $\mathbf{n}$ & $\%$ & $\bar{n}$ & $\%$ \\
\hline \multicolumn{5}{|l|}{ Umur kehamilan: } \\
\hline - 0 - 12 minggu & 0 & 0 & 2 & 3,2 \\
\hline • $13-27$ minggu & 8 & 12,7 & 21 & 33,3 \\
\hline - 28 - 40 minggu & 11 & 17,5 & 21 & 33,3 \\
\hline \multicolumn{5}{|l|}{ Pendidikan : } \\
\hline - SD & 4 & 6,4 & 10 & 15,8 \\
\hline • SMP & 5 & 7,9 & 16 & 25,4 \\
\hline - SMA/SMK & 10 & 15,9 & 15 & 23,8 \\
\hline • D3 & 0 & 0 & 1 & 1,6 \\
\hline - $\mathrm{S} 1$ & 0 & 0 & 2 & 3,2 \\
\hline Jumlah & 19 & 30,2 & 44 & 69,8 \\
\hline
\end{tabular}

penelitian ini ternyata yang terbanyak mengalami gejala ISK adalah ibu hamil dengan pendidikan terakhir SMA. Hal ini bisa disebabkan oleh kurangnya sumber informasi sehingga berdampak pada kurangnya pengetahuan ibu hamil. Teori menyebutkan kurangnya pengetahuan berhubungan dengan misinterpretasi informasi dan tidak mengenal sumber-sumber informasi. ${ }^{17}$

Dari penelitian ini dapat disimpulkan bahwa angka kejadian gejala ISK pada ibu hamil di Desa Mekar Galih masih tinggi yaitu sebesar $30,2 \%$, gejala ISK yang paling banyak dialami oleh ibu hamil adalah tidak bisa menahan buang air kecil, berdasarkan karakteristik ibu hamil, kejadian gejala ISK terbanyak pada umur kehamilan 28-40 minggu, dan pada pendidikan responden SMA/SMK.

Dalam penelitian ini terdapat keterbatasan yaitu data penelitian diambil menggunakan teknik wawancara dan kuesioner sehingga mungkin saja jawaban yang diberikan oleh sampel tidak menunjukkan keadaan sesungguhnya. Penulis menyarankan beberapa hal untuk ibu hamil, remaja, dan masyarakat lainnya tentang perlunya mengikuti pendidikan/penyuluhan kesehatan tentang bahaya infeksi saluran kemih, untuk menghindari dan mengurangi resiko terjadinya infeksi saluran kemih, lalu saran untuk bidan desa yaitu hendaknya dilakukan tindak lanjut dari hasil penelitian ini dengan cara merujuk ibu hamil yang mempunyai gejala ISK ke fasilitas kesehatan yang lebih lengkap. Hal ini bertujuan agar dapat dilakukan pemeriksaan lanjut di laboratorium guna memastikan diagnosis ibu, sehingga dapat dilakukan penanganan lebih lanjut seperti mendapatkan pengobatan dokter. 


\section{Daftar Pustaka}

1. Pertamigraha Adina. Prevalensi Infeksi Saluran Kemih pada Wanita Hamil Berdasarkan Hasil Pemeriksaan Urinalisis Rutin di Puskesmas Sukawarna Bandung. Maranatha Repository System [internet]. 13 Sept 2012 [dikutip 25 Maret 2015]. Dari : http://repository.maranatha.edu/id/ eprint $/ 1798$

2. Bolton $\mathrm{M}$, Horvath DJ Jr, Cortado H. Intrauterine growth restriction is a direct consequence of localized maternal uropathogenic Escherichia coli cystitis. Plos One. 2012; 7: 338-97.

3. Dwyer PL, O'Reilly M. Recurrent urinary tract infection in the female. Curr Opin Obstet Gynecol. 2002;14:537-43.

4. Cunningham FG, Leveno KJ, Bloom SL, Hauth JC, Rouse DJ, Spong CY. Williams Obstetrics 23rd ed. USA: McGraw-Hill. 2010.

5. Dinas Kesehatan Kabupaten Sumedang Puskesmas DTP Jatinangor. Profil Puskesmas DTP Jatinangor. 2012.

6. Dinas Kesehatan Kabupaten Sumedang Puskesmas DTP Jatinangor. Laporan Hasil Kegiatan Kesehatan Ibu dan Anak Tahun 2012.

7. Giraldo PC, Araujo ED, Junior JE, do Amaral RL, Passos MR, Goncalves AK. The prevalence of urogenital infections in pregnant women experiencing preterm and full-term labor. Infect Dis Obstet Gynecol: 2012;241.

8. Rizvi M, Khan F, Shukla I, Malik A, Shaheen. Rising prevalence of antimicrobial resistance in urinary tract infections during pregnancy: necessity for exploring newer treatment options. J Lab Physicians. 2011; 3:98-103.

9. Hadisaputro S, Parsudi I, Pranarka K, Winarto. Bakteriuria di masyarakat (hubungannya dengan sosial ekonomi dan kesehatan pribadi / hygiene lingkungan). Jakarta :Medika. 2009; 9: 661-64.

10. Becker G.J. Urinary tract infection and reflux nephropathy in adults. New York : Med. Intern Indon. 2008;2: 1337 - 43.

11. Lipsky BA. Urinary tract infection in men. Ann Int Med 2008; 110: 138-48.

12. Platt R. Quantitative definition of bacteriuria. Am Med 2009; 110: 44-51.

13. Desmiwarti. Kekerapan bakteriuria asimtomatis pada pasien abortus spontan di RSUP Dr M Djamil Padang. Skripsi Bagian / SMF Obstetri \& Ginekologi F.K.U.Andalas RSUP Dr M Djamil Padang. 2009.

14. Santoso S, Dzen MS. Bakteriuria asimtomatik pada wanita hamil. MajKedoktIndon 2005; 35:515-18

15. Ocviyanti D, Fernando D. Tatalaksana dan pencegahan infeksi saluran kemih pada kehamilan. J Indon Med Assoc. 2012; 62:482-5.

16. Kasper DL, Braunwald E, Fauci AS, Hauser SL, Longo DL, Jameson JL. Harrison's principles of internal medicine 16th ed. New York: McGraw-Hill. 2005; 1715-17.

17. MuttaqinArif. Buku Ajar Asuhan Keperawatan Kliendengan Gangguan Sistem Persarafan. Jakarta: Salemba Medika. 2008:287.

18. Drs. Saifudin Azwar, MA. Reliabilitas dan Validitas, Ed 3. Yogyakarta : Pustaka Pelajar. 2012: 82-170.

19. Munthe IG. Perbandingan Kejadian Bakteriuria sebagai Penyebab Infeksi Saluran Kemih pada Ibu Hamil dengan Ibu tidak Hamil. Medan: Repository USU [Internet]. 28 Mei 2014 [dikutip 25 Maret 2015]. Dari: repository.usu.ac.id 